\title{
Da fome à segurança alimentar: retrospecto e visão prospectiva
}

Há quase 60 anos, com a promissora emergência de idéias, movimentos e estatutos que se seguiram a Segunda Guerra Mundial, a luta contra a fome e a concepção de um estado de segurança alimentar e bem-estar nutricional passaram a figurar como grandes desafios no ideário das sociedades civis e na agenda dos poderes públicos. Assinala-se hoje um movimento no sentido de praticar a segurança alimentar como um referencial obrigatório dos direitos de cidadania. É o que está estabelecido no Pacto Internacional dos Direitos Econômicos, Sociais e Culturais. Mais do que os compromissos formais de signatário desse pacto, o Brasil representa antecedentes históricos valiosos que, agora, na grande mobilização do chamado "Projeto Fome Zero", devem ser resgatados.

No pós-guerra, o brasileiro Josué de Castro impactou o mundo com sua Geografia da Fome. Traduzido em mais de 20 idiomas e logo seguido pela Geopolítica da Fome, esses livros foram decisivos para a consolidação de um movimento internacional para a segurança alimentar - o Fundo das Nações Unidas para a Agricultura e Alimentação. No caso do Brasil, as idéias de Josué de Castro foram fundamentais para a instituição do salário mínimo, que estabeleceu uma cesta de 12 alimentos, que comprometeria $50 \%$ da estimativa salarial e atenderia $100 \%$ das recomendações de calorias, proteínas, sais minerais e vitaminas.

No que pesem esses antecedentes, o Brasil não tem cumprido uma trajetória correta nessa área. Apesar de desfrutar de uma situação cômoda, com uma oferta potencial de 3 mil calorias por habitante/dia, bem acima das necessidades estimadas de 2.200 calorias, observam-se sérias vulnerabilidades na cadeia armazenagem-comercialização-consumo e, sobretudo, no elo terminal do ciclo, isto é, na instância da utilização biológica, face ao perfil de co-morbidades que interagem com o estado nutricional. Como reflexo desse quadro, cerca de $10 \%$ de nossas crianças apresentam déficit de altura, e entre $15-30 \%$, deficiência de vitamina A. A anemia afeta $20 \%$ dos escolares, $30-40 \%$ das gestantes e entre $40-50 \%$ das crianças de 6-60 meses, tornando-se o problema carencial de maior magnitude no país. Paradoxalmente, a obesidade cresce em escala epidêmica, praticamente tendo triplicado entre homens e mulheres adultos no último quarto do século XX.

A pobreza constitui mal sistêmico da estrutura econômico-social do Brasil, que figura dentre as nações com mais desigualdade de renda do mundo. Temos entre 40-45 milhões de pessoas discriminadas pela linha de pobreza, metade das quais formando o estrato da indigência. Ao lado das medidas estruturais destinadas a ampliar o mercado de trabalho e a aumentar o nível de renda familiar, necessariamente devem ser acionados programas específicos para atender às demandas de curto prazo. Nesta contingência estão previstas ou em andamento medidas como a formação de bancos de alimentos, distribuição de cestas básicas, cartão de alimentos, ampliação do Programa de Alimentação do Trabalhador (hoje com 7.800.000 comensais/dia) ou o Programa de Alimentação do Escolar, que já atinge 38 milhões de alunos. Com mais de 30 anos, este programa deve ser urgentemente revisado, incorporando novos papéis no contexto do "Fome Zero", inclusive adequando-o ao perfil epidemiológico dos problemas de alimentação e nutrição dos escolares, ao invés de trabalhar com pressupostos e apriorismos que podem (e devem) ser superados.

Urge, portanto, a adoção de uma agenda variada de medidas que devem ser competentemente coordenadas para que os objetivos da segurança alimentar e do bem-estar nutricional sejam definitivamente incorporados no exercício de um novo modelo de desenvolvimento econômico, social, político e cultural do Brasil. O "Projeto Fome Zero" pode ser emblemático neste sentido, tornando-se o centro de gravitação de uma proposta de mudanças que assuma como meta final abolir a linha de exclusão que demarca e deforma a sociedade brasileira. Não é uma tarefa fácil, pois a grande muralha do nosso apartheid tem uma história de cinco séculos. Mas vale a pena iniciar a caminhada para corrigir e resgatar esta dívida.

Malaquias Batista Filho

Instituto Materno Infantil de Pernambuco, Recife, Brasil. 


\section{From hunger to food security: retrospective and prospective views}

For nearly 60 years, with the promising emergence of ideas, movements, and treaties following World War II, the fight against hunger and the concept of a state of food security and nutritional well-being arose as major challenges in the ideals of civil societies and on government agendas. There is a trend towards practicing food security as an obligatory reference for citizens' rights in general. This concept is written into the International Pact for Economic, Social, and Cultural Rights. Beyond its formal commitments as a signatory to this pact, Brazil presents valuable historical antecedents which now deserve to be renewed in the national mobilization known as the "Zero Hunger Project".

In the post-War period, Brazilian Josué de Castro made an impact on the world with his Geography of Hunger, translated into more than 20 languages and soon followed by the Geopolitics of Hunger. The two books were decisive for the consolidation of the international food security movement in the Food and Agriculture Organization of the United Nations. In the case of Brazil itself, Josué de Castro's ideas were essential for establishing a national minimum wage, defining a basic basket of 12 foodstuffs that would cost $50 \%$ of the estimated wage and meet $100 \%$ of calorie, protein, mineral, and vitamin intake requirements.

Despite this historical background, Brazil has failed to take an appropriate course in the field of nutrition. Although enjoying a comfortable situation with a potential daily supply of 3 thousand calories per inhabitant, that is, well above the recommended minimum daily intake of 2,200 calories, the country suffers serious vulnerabilities in the storage-marketing-consumption chain and especially in the final link of this cycle, namely that of biological utilization, given the range of co-morbidities interacting with nutritional status. As a result of this situation, some $10 \%$ of Brazilian children present a height deficit or stunting and some $15-30 \%$ have vitamin A deficiency. Anemia affects $20 \%$ of Brazilian schoolchildren, $30-40 \%$ of pregnant women, and some $40-50 \%$ of children $6-60$ months old, thus making it the most serious nutritional deficiency problem in the country. Paradoxically, obesity has increased on an epidemic scale, having practically tripled among adult men and women in the last quarter of the $20^{\text {th }}$ century.

As the result of historically accumulated distortions, poverty has become a systemic ill in the socioeconomic structure of Brazil, considered among other countries in the world with the worst income inequality. Brazil has 40-45 million inhabitants living below the poverty line, half of whom are indigents. Along with structural measures aimed at expanding the work market and increasing family income levels, specific programs are urgently needed to meet short-term demands. In this area, measures are planned or under way to form food banks, distribute basic food baskets, provide food cards, expand the Workers' Meal Program (currently feeding 7,800,000 workers/day), and the School Meal Program, which now feeds 38 million school children. Having existed for over 30 years, the latter program requires an urgent review, incorporating new roles within the context of the "Zero Hunger Project", adjusting the program to the actual epidemiological profile of nutritional problems among Brazilian schoolchildren rather than working with presuppositions and predefined parameters that can (and must) be replaced.

It is thus urgent to adopt a varied and skillfully coordinated agenda in order for the goals of food security and nutritional well-being to be definitively incorporated into both the central concept of a new model for economic, social, political, and cultural development in Brazil. The "Zero Hunger Project" can be emblematic in this sense, become the center of gravity in a proposal for changes whose ultimate goal is to eliminate the line of exclusion demarcating and deforming Brazilian society. It is not an easy task, since the great wall of Brazilian apartheid has a history of five centuries. Yet it is both necessary and worthwhile to begin the march in order to pay this historical debt.

Malaquias Batista Filho

Instituto Materno Infantil de Pernambuco, Recife, Brasil. 